\title{
A gyermeki jogok érvényesülése az új Polgári Törvénykönyv Családjogi Könyvében
}

\author{
a Polgári Törvénykönyv Családjogi Könyve - Gyermekjogi Egyezmény - \\ a gyermeki érdekek védelme - gyermeki jogok
}

\begin{abstract}
Napjainkban mind a jogalkotás, mind a jogalkalmazás terén a gyermeki jogok fokozottabb érvényesülése figyelhető meg. Ezt jelzi egyrészről a gyermeki jogokat érintő, nemzetközi, európai uniós, valamint nemzeti jogszabályok és dokumentumok egyre növekvő száma. Emellett a jogalkalmazás területén is kifejezésre jut a gyermek érdekének és jogainak hangsúlyosabb érvényesülése, többek között a bírósági, hatósági döntések meghozatala során. A gyermeki jogok mikénti érvényesülése tehát olyan kérdés, amellyel minden embernek, így többek között a szülöknek, a jogalkotónak, a jogalkalmazónak, a pedagógusnak foglalkoznia kell. Ugyanis „az a mód, ahogyan a társadalom a gyermekeket kezeli, nemcsak a törődésének és az együttmüködésének a fokát jelzi, hanem jól tükrözi az adott társadalom igazságérzetét, a jövő iránti elkötelezettségét, valamint azt is, mennyire fontos számára az eljövendő generációk emberi feltételeinek javitása". ${ }^{1}$ Ez az idézet is rávilágít arra, hogy a gyermekek jogainak és érdekeinek figyelembevétele, valamint garantálása kiemelkedő jelentőséggel bír különösen olyan területeken, mint a jogalkotás vagy a jogalkalmazás. Így a bírósági, hatósági eljárások során is messzemenően érvényesülnie kell a gyermeki jogoknak, amely megítélésem szerint csak abban az esetben biztosítható, amennyiben a jogalkalmazó számára rendelkezésre állnak az ehhez szükséges jogi és egyéb eszközök. A jogi eszközök közül a legfontosabbnak a gyermeki jogokat garantáló jogszabályokat, dokumentumokat tartom, amelyek közé tartozik az e tanulmányomban vizsgált Polgári Törvénykönyv Családjogi Könyve ${ }^{2}$ (a továbbiakban: Családjogi Könyv) is.
\end{abstract}

\section{A gyermek érdekének fokozott védelme mint alapelv}

A gyermek érdekének védelme mint családjogi alapelv - a fontosságára és a jelentőségére tekintettel - a Családjogi Könyv élén került rögzítésre. ${ }^{3}$ Alapelvként

* Dr. Fazekas Ágota PhD-hallgató, Szegedi Tudományegyetem Állam- és Jogtudományi Doktori Iskola, fazekasagota@gyula.birosag.hu.

1 Az idézet Pérez de Cuellar egykori ENSZ-főtitkár által a Gyermekjogi Egyezménnyel kapcsolatos, 1989 szeptemberében, Olaszországban megtartott nemzetközi konferencián előadott beszédéből származik.

2 A Polgári Törvénykönyvröl szóló 2013. évi V. törvény Negyedik Könyv: Családjog.

3 Ptk. 4:2. $\S(1)$ bekezdés. 
történő szabályozása azért indokolt, mivel a gyermek - korából és helyzetéböl adódóan - a családi kapcsolataiban eleve a gyengébb fél helyzetében van, ha pedig nincsenek ilyen kapcsolatai, éppen azok hiánya miatt szorul különleges védelemre és támogatásra. ${ }^{4}$

A Családjogi Könyv a gyermek érdekének védelmét - a Gyermekjogi Egyezményhez ${ }^{5}$ képest - más megközelítésben szabályozza. Ugyanis míg a Gyermekjogi Egyezmény 3. cikkének 1. pontja a "gyermek mindenekfelett álló (avagy más megfogalmazásban: legföbb) érdeke" (the child's best interest) védelmét garantálja, addig a Családjogi Könyv a gyermek érdekének és jogainak "fokozott védelmét” írja elö. E megfogalmazás ugyanis hívebben adja vissza a "the child's best interest" kifejezés által leírt fogalmat, mivel a gyermek maga is a családi közösség tagja, így nem lehetséges valamennyi esetben kizárólag az ő érdekét figyelembe venni, hanem a családi közösség többi tagjának (szüleinek, testvéreinek) az érdekeit, a család anyagi teherbíró képességét is mérlegelni kell a döntéseknél. Így az érdekek és jogok „fokozott” védelme a számára az adott helyzetben a lehető legjobb, az érdekeire leginkább tekintettel lévő megoldás alkalmazását jelenti. ${ }^{6} \mathrm{~A}$ gyermek érdeke tehát nem mindig az egyetlen, mindenekfelett álló szempont, mivel előfordulhat, hogy egymással versengő vagy egymással ellentétben álló emberi jogi érdekek, illetve egyes gyermekek közötti vagy gyermekek és felnőttek közötti érdekek ütköznek egymással. Ugyanakkor a gyermek érdekeit valódi megfontolás alá kell vetni, vagyis bizonyítani kell, hogy a gyermek érdekeit megvizsgálták-e, és elsődleges szempontként figyelembe vették-e. ${ }^{7}$

A jogirodalom szerint a gyermeki jogok megfelelő érvényesülésének egyik garanciája a gyermek érdekének védelmét elöíró alapelv. E kötelezettség a gyermekkel kapcsolatos ellátás, ügyintézés stb. során a Gyermekjogi Egyezmény mellett a hazai jogszabályokban is (különösen a Családjogi Könyv, a Gyvt. ${ }^{8}$ ) megfogalmazást nyer, és irányadó a jogok és a kötelezettségek gyakorlói, alkalmazói és végrehajtói számára. ${ }^{9}$ Ennek alapján a gyermek érdekének alapelvi szintü védelme a Családjogi Könyv számos részletrendelkezésében, így különösen a házasság felbontása, az örökbefogadás, a szülői felügyelet gyakorlása, a gyámság, a lakáshasználat rendezése keretében megjelenik. Ez azt is jelenti, hogy a jogalkotó kiemelt jelentőséget tulajdonított ezen alapelv egyes családjogi viszonyokban való fokozott figyelembevételének.

4 KöRös András: Alapelvek. In: Körös András (szerk.): Polgári Jog - Családjog - Az új Ptk. magyarázata IIIIVI. HVG-ORAC, Budapest, 2013, 27-28.

5 A Gyermek jogairól szóló, New Yorkban, 1989. november 20-án kelt Egyezmény kihirdetéséről szóló 1991. évi LXIV. törvény.

6 KöRÖs (2013): i. m., 28.

7 MARSCHALKó Linda: Az örökbefogadás és a gyermek legjobb érdeke. lustum Aequum Salutare, 2013/2, 265279.

8 A gyermekek védelméről és a gyámügyi igazgatásról szóló 1997. évi XXXI. törvény.

9 Somfal Balázs: A gyermek legföbb érdeke, mint eljárási alapelv. In: Ünnepi tanulmánykötet Filó Erika kandidátus, egyetemi docens 70. születésnapjára. PTE ÁJK, Pécs, 2010, 356-357. 


\subsection{A gyermek érdeke a házasság felbontása során}

A válások számának növekedése az utóbbi fél évszázadban világjelenségnek tekinthetö, amely elsősorban a házassággal szemben támasztott társadalmi elvárások megváltozására vezethető vissza. Ugyanis a 20. század végére a házasság a civilizált világban olyan önkéntesen vállalt kapcsolattá vált, amelyet bármikor meg lehet szüntetni, ha az együttélés müködésképtelen. Ennek alapján az európai bontójogok nagyfokú liberalizálódása mellett (így például a vétkességi rendszer feldúltságon alapuló rendszerré való átalakulása, a közös megegyezésen alapuló bontási forma megjelenése) az utóbbi évtizedekben mindenütt előtérbe került a válással érintett kiskorú gyermekek hatékonyabb védelme és érdekeinek figyelembevétele. ${ }^{10}$ E tendencia a magyar házassági bontójogban is megfigyelhetö.

Ennek alapján a Családjogi Könyv - az európai joggyakorlattal összhangban elvi jelentőségü rendelkezésként rögzíti, hogy a házasság felbontásának valamenynyi formájánál a közös kiskorú gyermek érdekét figyelembe kell venni. ${ }^{11} \mathrm{~A}$ gyermek érdeke azonban eltérően jelentkezik a bontóperben attól függően, hogy a szülei válásáról vagy az őt közvetlenül érintő járulékos kérdések rendezéséről van szó. Ugyanis bár a gyermek érdekét a bíróságnak abban a kérdésben is mérlegelnie kell, hogy felbontsa-e a házasságot, avagy a keresetet elutasítsa-e, azonban a valóban teljesen és helyrehozhatatlanul megromlott házasságot, amelyben az életközösség helyreállítására már nincs remény, a gyermek érdekében sem lehet fenntartani. A jogirodalom szerint a gyermek érdeke a házasság felbontása kérdésében, hogy a házasság a gyermek számára a lehető legkisebb megrázkódtatással szúnjék meg. ${ }^{12}$ Ugyanakkor más a helyzet, amennyiben a házasság felbontása során a gyermekre kiható járulékos kérdésekröl (szülöi felügyelet rendezése, tartás, kapcsolattartás) is dönteni kell. Ugyanis e kérdések eldöntésénél a gyermek érdeke már nem csupán egy a vizsgálandó szempontok közül, hanem a gyermeki érdeknek - a Gyermekjogi Egyezmény 3. cikk 1. pontja alapján - elsődlegesen kell érvényesülnie. ${ }^{13}$ Ennek alapján a Családjogi Könyv úgy rendelkezik, hogy a szülői felügyelet gyakorlásának, a szülö és a gyermek közötti kapcsolattartásnak és a gyermek tartásának rendezése során a gyermek érdekének kell elsődlegesen érvényesülnie. ${ }^{14}$

A gyermek érdekével, kiegyensúlyozott fejlődésével függ össze a Családjogi Könyv azon új rendelkezése is, amely bevezette többek között a házasság felbontásával kapcsolatos vitás kérdések lehetséges rendezési útjaként a világ számos országában már alkalmazott mediációs eljárást. ${ }^{15} \mathrm{~A}$ Családjogi Könyv ezen új rendelkezésének a beiktatását az Európa Tanács Miniszteri Bizottságának a családi közvetítésről szóló ajánlása is szorgalmazta, amely szerint a bírósági eljárás során

10 KöRös András: „Fontolva haladás” - az új Ptk. Családjogi Könyve 2. rész: A házasság megszünésének szabályai. Családi Jog, 2005/3, 12-19.

11 Ptk. 4:21. § (5) bekezdés.

12 CsIKY Ottó: A házasság megkötése, felbontása - A házastársi tartás. HVG-ORAC, Budapest, $1999,93$.

13 Boros Zsuzsa: A házasság. In: Körös András (szerk.): Polgári Jog - Családjog - Az új Ptk. magyarázata IIII VI. HVG-ORAC, Budapest, 2013, 63.

14 Ptk. 4:21. $\S(6)$ bekezdés.

15 Ptk. 4:22. §. 
is törvényi lehetőséget kell adni a békés válás elösegitésére. Ugyanis a bírósági eljárástól független, a felek önkéntes részvételén és aktív közremüködésén alapuló mediáció alkalmasabbnak túnik a családi konfliktusok felelős, egyetértő és a későbbi jogvitákat inkább kizáró megoldásra. ${ }^{16}$ Másrészröl a Családjogi Könyvbe bevezetett mediációs eljárás a gyermeki érdek érvényre juttatását is lehetővé teszi azáltal, hogy a szülők az évekig tartó, mindenkit jelentősen megterhelő jogi csatározások helyett a mediáció segítségével kompromisszumos megoldásokat részesíthetnek elönyben. Az egyik ilyen eredményt jelentheti, ha a szülök a válásuk után a gyermekük érdekében továbbra is együtt tudnak müködni. Ennek többek között azért van jelentősége, mivel a válás esetén lélektani értelemben a gyermek számára nem szünik meg a család. ${ }^{17}$

\subsection{A gyermek érdeke az örökbefogadásnál}

Az örökbefogadás vonatkozásában is, amely jogintézmény elsődleges feladata a kiskorúak megfelelő családhoz juttatása és családban történő felnevelkedése, megjelenik a gyermek érdekének mint alapelvnek az érvényesülése és garantálása. Ez jut kifejezésre a Családjogi Könyv azon rendelkezésében, amely szerint a gyámhatóság az örökbefogadást a törvényi feltételek megléte esetén is akkor engedélyezi, ha az a kiskorú gyermek érdekében áll. ${ }^{18} \mathrm{E}$ körben fontos utalni arra, hogy a Családjogi Könyv csak a kiskorúak örökbefogadását ismeri el. Ugyanis a kodifikációs folyamatot megelőző években felmerült az a gondolat, hogy célszerű lenne megvizsgálni a nagykorúak örökbefogadásának lehetőségét is, mivel néhány európai ország (így például Franciaország) jogrendszere a nagykorú személyek tekintetében is szabályozza e jogintézményt. ${ }^{19}$ Annak, hogy a Családjogi Könyv - megtartva a korábbi szabályozást - kizárólag a kiskorúak örökbefogadását ismeri el, indoka egyrészről az, hogy az örökbefogadás céljai alapvetően a kiskorú gyermek (akinek a szülei nem élnek, vagy akit a szülei megfelelöen nevelni nem képesek) örökbefogadását indokolják. Másrészröl a nagykorúak örökbefogadásával elérni kívánt célok más jogi eszközökkel (például névváltoztatással, örökössé tétel végintézkedéssel stb.) is elérhetőek.

A kiskorú gyermek érdeke, azaz a testi, értelmi és erkölcsi fejlődésének, személyi és vagyoni jogainak biztosítása tehát az örökbefogadás engedélyezésének alapvető feltétele. İ́gy a gyámhatóság - a gyermek érdekében - általános ellenőrzési jogosítványt kap az örökbefogadás létrejötte tekintetében, hogy a kiskorú családi

16 Texts of Recommendation No. R (98) 1 of the Committee of Ministers to Member States on Family Mediation - Council of Europe DIR/JUR (98) 4.

17 HÁmoRı Vilmos: Pszichológia a házassági bontó- és gyermekelhelyezési perben. Magyar Jog, 1989/3, 244254.

18 Ptk. 4:120. $\S(5)$ bekezdés.

19 KöRÖs András: „Fontolva haladás” - az új Ptk. Családjogi Könyve 12. rész: Az örökbefogadás I. Családi Jog, 2008/1, 2. 
neveléséröl az összes szóba jöhető körülmény alapján döntsön. ${ }^{20} \mathrm{~A}$ gyermek érdekének figyelembevétele az örökbefogadás engedélyezésénél azért is kiemelkedő fontosságú, mivel az örökbefogadásnak a központi alanya és kiindulópontja a gyermek, az eljárás is azért indul, mert a gyermek helyzete ezt igényli, ez adja az örökbefogadás létjogosultságát, nem pedig az örökbefogadók gyermek utáni vágya. ${ }^{21} \mathrm{Az}$ örökbefogadási eljárásban tehát többféle érdek ütközik, így sokszor nehéz feladat elsősorban a gyermek érdekét szem előtt tartva dönteni. llyen esetben azonban mindig a gyermek számára kell keresni a megfelelö örökbe fogadó családot, és nem a szülőnek keresni az általa elképzelt gyermeket. ${ }^{22}$

Ugyanakkor nem csupán az örökbefogadás engedélyezése, hanem annak felbontása során is érvényesülnie kell a gyermeki érdek védelmének. E követelmény jut kifejezésre a Családjogi Könyv azon rendelkezésében, amely szerint amennyiben az örökbe fogadott még kiskorú, úgy az örökbefogadás csak a kiskorú gyermek érdekében bontható fel. ${ }^{23}$ Ugyanis a gyermek érdeke elsősorban a családi környezet, családi nevelés biztosítása, azonban ha ezt az örökbefogadás már nem tudja nyújtani, úgy azt fel kell bontani.

Fontos továbbá megemlíteni néhány olyan családjogi rendelkezést az örökbefogadás vonatkozásában, amelyben bár konkrét jogszabályi utalás nincs a gyermeki érdek védelmére, azonban az érintett szabályozás - álláspontom szerint - közvetve ezen alapelv érvényesülését szolgálja. Így idetartozik a Családjogi Könyv azon új rendelkezése, amelyben az örökbefogadó személyével szemben támasztott egyik törvényi feltétel, azaz az örökbefogadási korhatár felemelésre került. Ennek alapján örökbefogadó csak 25 . életévét betöltött, cselekvőképes személy lehet, ${ }^{24}$ míg a Csjt.-ben az életkor szempontjából a nagykorúság volt a feltétel. E szabályozás hátterében egyrészről az áll, hogy az örökbefogadás akkor tudja betölteni a rendeltetését, ha a szülök erre a megfelelő életkorban vállalkoznak. Másrészről az európai jogrendszerek többsége sem elégszik meg a nagykorúsággal, hanem a gyermek neveléséhez szükséges érettség minél biztosabb megléte érdekében ennél magasabb életkort írnak elő. Így például Franciaországban 28 év, Svájcban 35 év, NagyBritanniában 25 év az elöírt korhatár. ${ }^{25}$

A gyermeki érdek érvényesülése jut kifejezésre az örökbefogadásra való alkalmasság megállapítása során is. ${ }^{26}$ Ugyanis egy előzetes eljárás és felkészítés lehetővé teszi annak a meghatározását, hogy az örökbe fogadó személy valóban alkalmas-e az örökbe fogadni szándékozó gyermek nevelésére. Emellett az örökbefogadó személyiségének megismerésén keresztül következtetni lehet az örökbefogadás tartósságának megalapozására is. Az örökbefogadásra alkalmasság egyik legfonto-

20 KatonÁnÉ Pehr Erika: Az örökbefogadás. In: Körös András (szerk.): A családjog kézikönyve. HVG-ORAC, Budapest, 2007, 451.

21 Marschalkó: i. m., 268.

22 Katonáné Pehr Erika: Az örökbefogadás. In: Körös András (szerk.): Polgári Jog - Családjog - Az új Ptk. magyarázata IIINI. HVG-ORAC, Budapest, 2013, 201.

23 Ptk. 4:138. $\S(2)$ bekezdés.

24 Ptk. 4:121. $\S(1)$ bekezdés.

25 KöRÖs (2008): i. m., 6.

26 Ptk. 4:122. §. 
sabb mércéjét jelenti az a gyermeki érdek érvényesülését biztosító rendelkezés is, amely szerint az örökbefogadás csak azt követően engedélyezhető, hogy az örökbe fogadni szándékozó személy a gyermeket legalább egy hónapig a saját háztartásában gondozta. ${ }^{27}$ Bár több külföldi jog ennél hosszabb gondozási időt ír elő (Svájc két év, Nagy-Britannia három hónap), ugyanakkor a magyar örökbefogadási szokások ismeretében (minél alacsonyabb életkorú gyermek örökbefogadására van igény) az egy hónap szükséges, de egyben megfelelő időtartam is ahhoz, hogy kiderüljön: konkrét esetben az örökbefogadás célja megvalósítható-e vagy sem. ${ }^{28}$

Végül a gyermeki érdek érvényesülését biztosítja az örökbefogadás utánkövetésének jogintézménye is, amely álláspontom szerint nagymértékben hozzájárulhat az örökbefogadás sikerességéhez, a szülö-gyermek kapcsolat problémamentes kialakulásához. Ugyanis az örökbefogadást engedélyező határozat jogerőre emelkedésétől számított legfeljebb öt évig jogszabályban meghatározott szervezet vagy a területi gyermekvédelmi szakszolgálat a gyermek helyzetét, életkörülményeinek alakulását figyelemmel kíséri és segíti. ${ }^{29}$ Ennek keretében a szakember szükség esetén tájékozódik a gyermek helyzetéről, és erről jelentést tesz az örökbefogadást engedélyező gyámhivatal számára. A nemzetközi tapasztalatok alapján egyes országokban (így például Ausztriában, Luxemburgban, Észtországban) az utánkövetés keretében igénybe vehető szolgáltatások (különösen a pszichológiai tanácsadás, a konzultáció, az önsegítő csoportok), valamint az utánkövetést végző szervezetek és az örökbe fogadó szülő közötti bizalmi kapcsolat hozzájárulhatnak az örökbefogadás sikerességéhez, így a gyermeki érdek messzemenő érvényesüléséhez.

\subsection{A gyermek érdeke a szülői felügyelet gyakorlása során}

A szülői felügyelet a családi jog azon területe, ahol a joggyakorlat szerint az alapvető gondok jelentkeznek: a szülők közötti véget nem érő jogi viták, a végrehajthatatlan hatósági határozatok, újból és újból fellángoló személyi összetüzések teszik tönkre sok gyermek életét, azokét, akiket - mint koruknál és helyzetüknél fogva gyengébb feleket - a jogszabályoknak és a jogalkalmazóknak elsősorban szolgálnia kellene..$^{30}$ Ugyanakkor az elmúlt időszakban megfigyelhetőek azok a jogalkotást is érintő változások, amelyek a szülői felügyelet során jelentkező gyermeki jogok hangsúlyosabbá tételét eredményezték. Így a szülői hatalomból, amely elsősorban nem a gyermek érdekeire fókuszált, szülői felügyelet lett, amely már szülői kötelezettségként jelenik meg, és kifejezetten a gyermek jólétét, érdekét kívánja biztosítani. ${ }^{31}$

A szülö-gyermek közötti jogviszony területén azonban még ma sem könnyű áttörést elérni abban a kérdésben, hogy a szülő nem a hatalmát gyakorolja a gyermeke

27 Ptk. 4:128. § (1) bekezdés.

28 KöRÖs (2008): i. m., 9.

29 Ptk. 4:131. $\S(2)$ bekezdés.

30 KöRös András: „Fontolva haladás” - az új Ptk. Családjogi Könyve 6. rész: A szülői felügyelet I. és II. fejezet. Családi Jog, 2006/3, 1-8.

31 SzEIBERT Orsolya: A gyermek meghallgatása az európai országok gyakorlatában - Németország, Svájc, Belgium, Franciaország. Családi Jog, 2014/3, 31-36. 
felett, hanem joga és kötelessége (és ez utóbbit különösen hangsúlyozni kell), hogy a gyermeke testi, értelmi és erkölcsi fejlödéséröl gondoskodjék. Kétségkívül a szülögyermek jogviszonyban a szülők és a gyermekek pozíciója különböző, nem egyenlő: a gyermek, bár önálló személyiség, kiszolgáltatott helyzetben van, és éppen ez a kiszolgáltatottsága indokolja e viszonyrendszerben a gyermek jogai érvényesítésének jogszabályi úton történő garantálását. A gyermek elöbb említett gyengébb pozíciójánál fogva a szülő-gyermek viszonyban a gyermek jogai és érdekei elsőbbséget élveznek. ${ }^{32}$

Az a tendencia, hogy a gyermeki érdek védelmének a szülői felügyelet gyakorlása során is kiemelkedő jelentősége van, megfigyelhető a Családjogi Könyvben is. Ez jut kifejezésre többek között azon rendelkezésben, amely szerint a szülői felügyeletet a szülők a gyermek megfelelő testi, szellemi és erkölcsi fejlődése érdekében, egymással együttműködve kötelesek gyakorolni. ${ }^{33} \mathrm{Az}$ együttmüködési kötelezettség nevesítésével a törvény a gyermeki érdek érvényesülését hangsúlyozza, amely mind az életközösség fennállása alatt, mind annak megszakadásakor követelmény.

A gyermeki érdek védelmének fontosságát jelzi, hogy amennyiben a szülök a szülöi felügyeleti jogokat nem a gyermek érdekének megfelelően gyakorolják, úgy kivételesen indokolt esetben, a gyermek érdekének biztosítása céljából hatósági beavatkozásra, azaz a szülői felügyeleti jog korlátozására vagy elvonására kerülhet sor. ${ }^{34} \mathrm{E}$ körben az Alkotmánybíróság megállapította, hogy a szülöi felügyelet a szülők részéről elsődlegesen kötelezettség. Ugyanakkor a gyermek védelme és a róla való gondoskodás nemcsak a család alkotmányos kötelessége, hanem az államé is. Így amennyiben a gyermeknek szülői kötelességet nem teljesítő szülője van, úgy helyettük az államnak kell helyt állnia. Ez ad a jogalkotónak lehetőséget a beavatkozásra, jelen esetben a szülői felügyelet elvonására vagy korlátozására. ${ }^{35}$

A gyermek érdekének védelme jelenik meg a szülöi felügyelet gyakorlásának bírósági rendezése során is. Ugyanis a bíróság - a különélő szülők megállapodásának hiányában - dönt arról, melyik szülö gyakorolja a szülöi felügyeletet - a korábbi terminológiát használva -, melyik szülónél helyezhető el a gyermek. E döntésnél a bíróság azt mérlegeli, hogy a gyermek testi, szellemi és erkölcsi fejlődése miként biztositható a legkedvezöbben.

Továbbá a gyermek érdekének védelme jut kifejezésre a Családjogi Könyv azon új rendelkezésében is, amely szerint a szülöi felügyelet gyakorlásával összefüggő jogviták rendezése során a közvetítői eljárásra nemcsak a szülők kérelmére, hanem a gyermek érdekében, hivatalból is sor kerülhet. Így az e területen igénybe vehető vagy elrendelt mediációs eljárás szintén a gyermeki érdek érvényesülését jelenti.

32 FıLó Erika: A szülöi felügyelet tartalma, részjogosítványai. In: Sáriné Simkó Ágnes (szerk.): Gyermeki jogok, szülői felelősség és gyermekvédelem. HVG-ORAC, Budapest, 2015, 79.

33 Ptk. 4:147. § (1) bekezdés.

34 Ptk. 4:149. §.

35 995/B/1990. AB határozat, ABH 1993, 515. 


\subsection{A gyámság alatt álló gyermek érdeke}

A családi környezettöl megfosztott gyermek az állam különleges védelmére és segítségére jogosult. Magyarországon a gyámság az a jogintézmény, amely a szülöi felügyeletet gyakorló szülő hiányában a kiskorú gyermek gondviselését, képviseletét és vagyonának kezelését a gyámhatóság által kirendelt gyám személyén keresztül biztosítja. Mivel a gyámság a gyermek számára a szülöt kívánja pótolni a kirendelt gyám személye útján, így annak ellátása során, ugyanúgy, mint a szülői felügyelet esetén, a kiskorú gyermek érdekének érvényesülnie kell. Ezt juttatja kifejezésre a Családjogi Könyv azon rendelkezése is, amely szerint a gyám a gyermek érdekeinek megfelelöen köteles a tevékenységét gyakorolni. ${ }^{36}$ Ugyanis a gyám kirendelésére a kiskorú gyermek személyes és vagyoni érdekeinek védelmében kerül sor.

A gyermek érdekeinek minél teljesebb érvényre juttatását szolgálják továbbá azon családjogi rendelkezések, amelyek szerint a gyámhatóság kivételesen felmentheti a gyámot, ha a gyermek érdekében más személy gyámként való kirendelése indokolt, ${ }^{37}$ illetve a gyámhatóság a gyámot elmozdíthatja, ha a gyámsága alatt álló gyermek érdekeit súlyosan sérti vagy veszélyezteti. ${ }^{38} \mathrm{~A}$ gyámi tisztség megszüntetése a gyámhatóságnak a gyámot felmentő vagy elmozdító határozatával következhet be. A felmentés és az elmozdítás jogi hatása lényegében egyező, közöttük az érdemi eltérés elsősorban az, hogy a gyám elmozdítására a gyám felróható magatartása miatt kerül sor. $E$ körben a felróható magatartások eseteit az új kódex kiegészítette ${ }^{39}$ a jogirodalom által szorgalmazott, a gyámság alatt álló érdekeit súlyosan sértő vagy veszélyeztető cselekménnyel, amely összefügg azzal a követelménnyel, hogy a gyám a tevékenységét mindenkor a kiskorú gyermek érdekében köteles kifejteni. ${ }^{40}$

\subsection{A gyermek érdeke a lakáshasználat rendezése során}

A lakás az ember egyik alapvetö létszükséglete, ezért a házastársi, élettársi közös lakás sem csupán közös ingatlan, tulajdon vagy bérlemény, hanem ennél több: a család otthona, amelyet a jognak e minőségben védenie kell. A szülök közös lakása szolgál tehát a család otthonául, amely a családi együttélés és a gyermekek gondozásának, nevelésének alapvető „színtere”. Mivel a közös otthon védelmét elsősorban a közös kiskorú gyermek érdeke indokolja, így többek között a jogalkotónak, a jogalkalmazónak, de elsősorban a szülőknek kell kiemelt védelemben részesíteniük a kiskorú gyermek lakáshasználathoz füződő jogát. Ez jut kifejezésre a szülöi felügyelet körében a Családjogi Könyv azon rendelkezésében, amely szerint a szülök a saját háztartásukban a kiskorú gyermek gondozásának, nevelésének

36 Ptk. 4:234. § (1) bekezdés.

37 Ptk. 4:241. $\S(2)$ bekezdés.

38 Ptk. 4:242. $\S(1)$ bekezdés.

39 Lásd erröl bővebben KATONÁNÉ PEHR Erika: A gyámság kérdései és a gyámhatóságok családjogi jellegü feladatai - Kézirat. Budapest, 2000, 30.

40 KöRös András: „Fontolva haladás” - az új Ptk. Családjogi Könyve 14. rész: A gyámság. Családi Jog, 2008/3, $1-11$. 
keretein belül kötelesek biztosítani a gyermekük lakhatását is. ${ }^{41}$ Ezt erösíti meg a Családjogi Könyv további szabálya is, ${ }^{42}$ amely szerint a házastársak (élettársak) kiskorú gyermekének lakáshasználatát a házastársi közös lakásban kell biztosítani. Emellett a törvény a lakáshasználat rendezésére vonatkozó szabályok alkalmazása szempontjából - a bírói joggyakorlatot követve ${ }^{43}$ - a házastársak közös kiskorú gyermekén kívül lakáshasználatra jogosultnak tekinti a lakás használatára kizárólagos jogcímmel rendelkező házastárs kiskorú gyermekét is. ${ }^{44} \mathrm{E}$ szabályok egyrészről azt jelentik, hogy a kiskorú gyermeknek alanyi joga van szüleivel szemben arra, hogy közös lakásukban (az életközösség megszünése után valamelyikük lakásában) elhelyezéséröl gondoskodjanak, akkor is, ha nem bérlőtársként vagy tulajdonosként, hanem családtagi minőségben lakik velük. Fontos utalni azonban arra, hogy bár e rendelkezések kiskorú gyermekre vonatkoznak, a gyermek lakáshasználati jogát önmagában a nagykorúság elérése nem szünteti meg, ugyanis tipikus esetként például a szülök ezt követően is kötelesek gondoskodni a továbbtanuló nagykorú gyermekük tartásáról.

Emellett a Családjogi Könyv mind a házastársak, mind az élettársak lakáshasználata vonatkozásában több olyan rendelkezést is tartalmaz, amely a gyermeki érdekek és jogok érvényesülését biztosítja a lakáshasználat rendezésekor. Így például a közös lakással való rendelkezés során a kizárólagos jogcímmel rendelkező házastársnak tekintettel kell lennie különösen a lakásban lakó kiskorú gyermek érdekeire..$^{45}$ Ugyanígy a lakáshasználat előzetes, valamint az életközösség megszűnése utáni szerződéses rendezésekor is figyelemmel kell lenni a gyermek érdekére. A lakáshasználatot előzetesen rendező szerződés tekintetében külön kiemeli a Családjogi Könyv, hogy amennyiben e szerződés a kiskorú gyermek lakáshasználati jogával kapcsolatosan rendelkezést nem tartalmaz, vagy olyan rendelkezést tartalmaz, amely a lakáshasználat rendezésekor a kiskorú gyermek megfelelő lakáshoz füződő jogát súlyosan sérti, a bíróság a gyermek érdekében a közös lakás használatát a szerződésben foglaltaktól eltérően rendezheti. ${ }^{46} A$ joggyakorlat alapján a gyermek érdekének súlyos sérelme akkor valósul meg, ha a szerződés szerinti rendezés őt lényegesen rosszabb élet- és lakáskörülmények közé kényszerítené. ${ }^{47}$

A szerződéses rendezésnél lényegesen gyakoribb az az eset, hogy a házasság felbontása vagy az életközösség megszűnése esetén a bíróság dönt a közös lakás további használatáról. E döntéshozatal során a bíróságnak törekednie kell arra, hogy a lakáshasználat rendezése különösen a lakáshasználatra jogosult gyermek érdekeinek megfeleljen. A lakáshasználat valamennyi rendezési módjánál a gyermek érdekére figyelemmel kell lenni. Így például a bíróság nem rendelhet el osztott lakáshasználatot a közös jogcímen lakott lakás vonatkozásában, ha az egyik házastárs (élettárs) olyan felróható magatartást tanúsít, amely miatt a közös lakáshasználat a

41 Ptk. 4:152. $\S(2)$ bekezdés.

42 Ptk. 4:76. § (2) bekezdés.

$43 \mathrm{BH}$ 1992. 764.

44 Ptk. 4:76. § (3) bekezdés.

45 Ptk. 4:77. $\S(3)$ bekezdés.

46 Ptk. 4:79. $\S(2)$ bekezdés.

47 BH 2007. 1698. 
másik házastárs (élettárs) vagy a kiskorú gyermek érdekeinek súlyos sérelmével járna. ${ }^{48} \mathrm{Az}$ ítélkezési gyakorlat az olyan magatartásokat tekinti súlyosan sérelmesnek a gyermekre, amelyek lehetetlenné, elviselhetetlenné teszik a további együttlakást, így például a másik házastárs botrányos, garázda magatartása, ${ }^{49}$ állandó feszült légkör teremtése, amely a kiskorú gyermek zavartalan fejlödését gátolja, személyiségét eltorzíthatja. ${ }^{50}$ Amennyiben a házastársak a házastársi közös lakást egyikük kizárólagos jogcíme alapján használják, az e kizárólagos jog gyakorlásához füződő érdek ütközhet családvédelmi, illetve gyermeki érdekkel. Az egymással ütköző érdekek mérlegelése során a bíróság az adottságainál fogva alkalmas lakás osztott használatát is elrendelheti a lakáshasználatra jogosult kiskorú gyermek érdekében, ha a gyermek vagy több gyermek esetén legalább egyikük feletti szülői felügyeleti jog gyakorlását a másik házastársnak biztosította. Kivételesen indokolt esetben a bíróság a lakás kizárólagos használatára a másik házastársat is feljogosíthatja, ha a lakáshasználatra jogosult kiskorú gyermek feletti szülői felügyeleti jog gyakorlása őt illeti meg, és a kiskorú gyermek lakhatása másként nem biztosítható, ${ }^{51}$ így például a lakás nem osztható meg, elköltözni nem tudnak. E vonatkozásban az Alkotmánybíróság a tulajdonjognak családvédelmi alapon, a gyermek érdekében történő korlátozását nem találta alkotmányellenesnek. ${ }^{52}$

\section{A családban történő nevelkedéshez és a családi kapcsolatok fenntartásához való jog mint alapelv}

A családban történő nevelkedéshez és a családi kapcsolatok fenntartásához való jog fokozottabb érvényesülése figyelhető meg a nemzetközi, az európai uniós és a hazai jogalkotás során. Ezt jelzi hazánkban többek között az is, hogy a Családjogi Könyv e gyermeki jogokat - jelentőségükre tekintettel - alapelvi szintre emelte. Valamennyi családjogi viszonyban elötérbe kell kerülnie azon elvárásnak, hogy a gyermek családban, illetve családi környezetben nőjön fel, valamint a korábbi családi kapcsolatait fenntarthassa. E követelményt fogalmazza meg a gyermeki jogok nemzetközi alapdokumentumának tekinthető Gyermekjogi Egyezmény is egyrészről annak kimondásával, hogy a család a társadalom alapvető egysége, továbbá a gyermek személyiségének harmonikus kibontakozásához szükséges, hogy családi környezetben nőjön fel. ${ }^{53}$ Másrészről a Gyermekjogi Egyezmény kifejezetten deklarálja a szülők általi neveléshez $z^{54}$ és a családi kapcsolatok megtartásához ${ }^{55}$ való gyermeki jogokat. Továbbá ez az Egyezmény biztosítja a gyermek azon jogát is, hogy nem szabad a szüleitöl az ő akarata ellenére elválasztani, kivéve, ha ez a gyermek mindenekfelett álló érdekében szükséges.

48 Ptk. 4:81. § (4) bekezdés.

$49 \mathrm{BH}$ 1978. 205.

$50 \mathrm{BH}$ 1994. 542.

51 Ptk. 4:83. § (2) és (3) bekezdés.

52 2299/B/1991. AB határozat, ABH 1992, 570.

53 Gyermekjogi Egyezmény: Bevezetés.

54 Gyermekjogi Egyezmény 7. cikk 1. pont.

55 Gyermekjogi Egyezmény 8. cikk 1. pont. 
E gyermeki jogok a jogirodalom szerint a gyermek identitáshoz való jogát határozzák meg. Ugyanis a gyermek személyiségének megfelelő kialakulása szempontjából kiemelkedő jelentősége van a családi kapcsolatoknak, kötődéseknek, melyek kialakítják a gyermek identitását. Következésképpen az identitáshoz való jog azt jelenti, hogy a gyermek számára biztosítani kell a valódi családdal, illetve közösséggel való azonosság megőrzését, fenntartását, függetlenül attól, hogy az a vér szerinti-e vagy sem. ${ }^{56}$

E gyermeki jogokat a Családjogi Könyv az alapelvek között rögzíti. Ugyanis elvi jelentőségű - a gyermek érdekeinek fokozott védelmének hangsúlyozása mellett - annak a kimondása, hogy a gyermeknek joga van a saját családjában, ennek hiányában a családi környezetben való nevelkedéshez, valamint a korábbi családi kapcsolatainak megtartásához.

A családban történő nevelkedéshez való jog - ugyanúgy, mint a gyermek érdekének védelme esetében - a Családjogi Könyv több részletszabályában megtalálható. Ez az alapelv jelenik meg például az örökbefogadás törvényi céljai között is. Ugyanis az örökbefogadás célja, hogy az örökbefogadó, annak rokonai és az örökbe fogadott gyermek között rokoni (azaz családi) kapcsolatot létesítsen az örökbe fogadott gyermek családban történő nevelkedése érdekében. ${ }^{57} \mathrm{E}$ körben az örökbefogadás családjogi jellegét az adja, hogy vérségi kapcsolatban nem álló személyek között létesít rokoni kapcsolatot. A családi kapcsolatot a harmonikus, kiegyensúlyozott légkörű családi közösségben való nevelés érdekében létesíti, amely a gyermeknek testi, szellemi és erkölcsi fejlődése biztosítására - a legkedvezőbb.

A gyermek korábbi családi kapcsolatainak fenntartásához való jogát garantálja a Családjogi Könyv többek között azon rendelkezésében, amely szerint kivételesen indokolt esetben a gyámhatóság nyílt örökbefogadás esetén meghatározott feltételekkel a vér szerinti szülöt feljogosíthatja a kapcsolattartásra. ${ }^{58}$ Ugyanis egyes esetekben indokolt lehet, hogy az örökbe fogadott gyermek a vér szerinti szüleivel továbbra is tarthassa a kapcsolatot. Ennek indokát a jogirodalom a gyermek identitáshoz való jogából vezeti le, mivel az örökbefogadás eredményeként a vér szerinti rokonsággal való kapcsolat, kötődés teljes megszakadása kifejezetten sérelmes lehet a gyermek személyiségfejlődése szempontjából. ${ }^{59}$

\section{A meghallgatáshoz és a véleménynyilvánításhoz való jog}

A véleménynyilvánításhoz való jog életkorra tekintet nélkül mindenkit megillető emberi jog. Napjainkban a szülö-gyermek kapcsolat, amelynek jogosultja a gyermek, kötelezettje a szülö, az állam és a társadalom, hangsúlyosabbá válása folytán a gyermek azon joga is előtérbe került, hogy a véleményét és álláspontját szabadon kifejthesse. Így a Gyermekjogi Egyezmény 12. cikke is rögzíti, hogy az ítélöképes-

56 SzEIBERT Orsolya: Középpontban a gyermekek: a kiskorú szülök helyzete és a gyermek identitáshoz füződő joga. Családi Jog, 2005/3, 20-26.

57 Ptk. 4:119. $§(1)$ bekezdés.

58 Ptk. 4:133. § (4) bekezdés.

59 Szeibert (2005): i. m., 20-26. 
sége birtokában lévő gyermek számára biztosítani kell azt a jogot, hogy minden őt érintő kérdésben szabadon kinyilváníthassa véleményét. $E$ körben a gyermek véleményét, figyelemmel korára és érettségi fokára, figyelembe kell venni. Ebből a célból a gyermeknek lehetőséget kell adni arra, hogy bármely olyan közigazgatási vagy bírósági eljárásban, amelyben érdekelt, közvetlenül vagy képviselője, illetve arra alkalmas szerv útján a hazai eljárási szabályoknak megfelelően meghallgassák.

Másrészröl a gyermek véleménynyilvánítási jogának fokozottabb érvényesülését láthatjuk az európai jogalkotási, illetve jogalkalmazási trendekben is. Így például a német, a francia, a belga vagy a svájci jogrendszer az, ${ }^{60}$ amely kiemelt jelentőséget tulajdonít a gyermek meghallgatáshoz és véleménynyilvánításhoz való jogának.

Hazánkban a gyermek véleménynyilvánításhoz és meghallgatáshoz való jogát garantálja többek között a Családjogi Könyv azáltal, hogy e jog érvényesülését számos részletrendelkezésében biztosítja. Emellett az új kódex családjogi szabályozásában is megfigyelhetőek azok a jogirodalom által megfogalmazott paradigmaváltozások, amelyek elsősorban a szülő-gyermek viszony átalakulásával (a gyermek jogosult, a szülö, állam, társadalom kötelezett), illetve a gyermek szerepének, véleményének és álláspontjának fokozottabb figyelembevételével kapcsolatosak. Ezt támasztja alá a törvény szülői felügyelet gyakorlásával kapcsolatos azon rendelkezése is, amely szerint a szülőknek tájékoztatniuk kell a gyermeküket az őt érintő döntésekről, biztosítaniuk kell, hogy az ítélőképessége birtokában lévő gyermekük a döntések előkészítése során véleményt nyilváníthasson, a törvényben meghatározott esetben a szüleivel közösen dönthessen. A szülöknek a gyermek véleményét - korára, érettségére tekintettel - megfelelő súllyal figyelembe kell venniük. ${ }^{61}$

A véleménynyilvánítási jog fokozottabb szerepét jelzi, hogy a Családjogi Könyvben - a Csjt.-hez képest - nagyobb hangsúlyt kap az a gyermeki jog, hogy a gyermeket a szülőnek be kell vonnia a vele kapcsolatos döntési folyamatba. Ez összhangban áll az Európai Családjogi Bizottság azon elvével, hogy a gyermek meghallgatásának nemcsak az őt érintő eljárásokban, hanem a mindennapi életvitel során is jelentőséget kell tulajdonítani. ${ }^{62}$ Ugyanis a szülöi felügyelettel kapcsolatos döntéseknek a gyermek nem passzív tárgya, hanem aktív résztvevője. Ezt hangsúlyozta a Kúria is azon döntésében, amelyben kimondta, hogy a szülőnek a gyermekét partnernek kell tekintenie, továbbá a gyermek véleményének kikérése a mindennapi élet apróbb eseményeivel és meghatározó jellegü döntéseivel kapcsolatban egyaránt szükséges lehet. ${ }^{63}$

A Családjogi Könyv több fokozatot állapít meg arra vonatkozóan, hogy a gyermek milyen módon vonható be az őt érintő döntési folyamatokba. ${ }^{64}$ Ennek értelmében az első fokozat, amikor a szülőnek tájékoztatnia kell a gyermekét az őt érintő dön-

60 Lásd bővebben Löhnig, Martin-Schwab, Dieter-Henrich, Dieter-Gottwald, Peter (Hrsg.): Kindesrecht und Elternkonflikt. Gieseking, Bielefeld, 2013.

61 Ptk. 4:148. §.

62 Európai Családjogi Bizottság (Commission on European Family Law) Elvei a szülöi felügyeleti jogok kérdéskörében, II. fejezet 3:6 Elv: A gyermek meghallgatáshoz való joga.

63 A Kúria Pfv.ll.20.799/2012/5. számú ítélete.

64 Makal Katalin: A szülői felügyelet. In: Kőrös András (szerk.): Polgári Jog - Családjog - Az új Ptk. magyarázata IIIVI. HVG-ORAC, Budapest, 2013, 237. 
tésekröl, így például, ha a szülök válni szándékoznak, és a szülői felügyelet mikénti gyakorlása érinti a gyermek jövőbeni sorsát. A második fokozat azokra az esetekre vonatkozik, amikor a törvény a gyermek és a szülő közös döntését kívánja meg, így különösen a gyermek életpályájával, a taníttatásával, az iskolájának megválasztásával kapcsolatban. ${ }^{65}$ Végül vannak olyan esetek is, amikor a gyermek - a törvényi rendelkezések értelmében - egyedül, önállóan hozhat döntést. Így például a korlátozottan cselekvőképes kiskorú az örökbefogadással kapcsolatos jognyilatkozatokat személyesen, törvényes képviselője hozzájárulása nélkül teheti meg. ${ }^{66}$

Az eddig ismertetett, a gyermek véleménynyilvánítási jogával kapcsolatos családjogi rendelkezések azokra az esetekre vonatkoztak, amikor a szülö kötelezettsége, hogy a gyermekét az őt érintő döntésekben meghallgassa, véleményét kikérje, illetve vele közösen döntsön. Ugyanakkor a Családjogi Könyv a gyermek meghallgatásával, véleményének kikérésével összefüggésben szabályozza azokat az eseteket is, amikor a bíróságnak, illetve a gyámhatóságnak a kötelezettsége a hatósági eljárás során a gyermeket meghallgatni, véleményét figyelembe venni. llyen esetről beszélhetünk például akkor, amikor a szülök megegyezésének hiányában a bíróság dönt a gyermeket érintő lényeges kérdésekröl, így különösen arról, hogy a jövőben melyik szülő fogja gyakorolni a szülői felügyeleti jogot. ${ }^{67}$ Ennek alapján a bíróságnak a szülői felügyelet gyakorlásának rendezése és a gyermek harmadik személynél történő elhelyezése iránti eljárásában, indokolt esetben, vagy ha azt a gyermek maga kéri, közvetlenül vagy szakértő útján a gyermeket meg kell hallgatnia. E szabályozásból kitúnik, hogy a gyermek immár nem tárgya az őt érintő döntéseknek és eljárásoknak, hanem olyan legföbb érdekeltje, akiért az eljárás minden résztvevője (azaz a hatóságok, a szülők, a jogi képviselök, a szakértők stb.) fokozott felelösséggel tartozik. Ugyanakkor fontos hangsúlyozni, hogy a kiskorú véleményalkotása abban a kérdésben, hogy melyik szülönél kíván maradni, csak jog és semmiképpen nem kötelesség. Ezt fejezi ki Weiss Emília is abban a tanulmányában, amelyben úgy foglal állást, hogy „a gyermek nem kötelezhetö arra, hogy maga döntse el, melyik szülő legyen a szülői felügyeletet gyakorló szülöje”. ${ }^{68}$

A Családjogi Könyv a gyermek meghallgatásának lehetőségét, illetve szükségességét a Gyermekjogi Egyezményben foglaltakkal összhangban rögzíti. Ugyanis e törvény nem állapít meg olyan életkort, amelynek betöltését követően a gyermeket mindenképpen meg kell hallgatni, mivel ez mindig az ügy jellegétől, a gyermek fejlettségétől és attól függ, hogy a gyermek ítélőképessége birtokában van-e. Így a Családjogi Könyvben a gyermek meghallgatásának nincsen alsó életkori határa, ${ }^{69}$

65 Ptk. 4:153. § (2) és (3) bekezdések.

66 Ptk. 4:145. $\S(1)$ bekezdés.

67 Ptk. 4:171. § (4) bekezdés.

68 WeISs Emília: Változások a magyar családjogban - különös tekintettel a gyermek jogairól szóló 1989. évi New York-i Egyezményre. Közjegyzők Közlönye, 1998/9, 2-5.

69 A magyar bírói gyakorlat általában a tizenkét évet tekinti annak a korhatárnak, amelynél már érdemleges vélemény várható a gyermektől. Ugyanakkor a per egyéb adataiból kiderülhet, hogy a kiskorú akár tizenkét év alatt is rendkívül érett és fejlett, ítélöképes, de előfordulhat az is, hogy egy tizenhat éves tinédzser nem tud érdemben nyilatkozni. Lásd ÁDÁmkó Viktória: Az ítélőképessége birtokában lévő gyermek véleményének meghallgatása - különös tekintettel a gyermekelhelyezésre. Családi Jog, 2015/3, 11. 
hanem a bíró felelössége, hogy eldöntse, mikor indokolt a gyermek személyes részvétele, meghallgatása az eljárás során, illetve mikor szükséges pszichológus szakértő útján tájékozódni a gyermek véleményéről, kötődéséről. Ugyanakkor az európai jogrendszerekben léteznek olyan szabályozások, amelyek a gyermek meghallgatása vonatkozásában alsó életkort határoznak meg. Így például a svájci jog szerint, amennyiben a meghallgatás bizonyítási eszköz lehet, úgy a gyermeket a hatodik életév betöltése után meg kell hallgatni. ${ }^{70}$ Továbbá a norvég jog ezen alsó korhatárt a 7. életévben, a bolgár jog pedig a 10. életévben határozza meg. ${ }^{71}$ Ezzel szemben a belga, a francia vagy a szlovák jog - hasonlóan a magyar szabályozáshoz - nem állapít meg alsó korhatárt, hanem a bíró döntésére bízza, hogy a gyermek hány éves korától tekinthető ítélőképesnek.

A Családjogi Könyv rendelkezései szerint tehát a gyermek meghallgatására életkorától függetlenül - abban az esetben kerülhet sor, ha ítélőképessége birtokában van. Ugyanakkor a törvény szabályoz olyan eseteket is, amelyben a gyermek életkorának jelentősége van. Így például amennyiben a gyermek a 14. életévet betöltötte, a szülői felügyeletére és elhelyezésére vonatkozó döntés egyetértésével hozható, kivéve, ha a gyermek választása a fejlődését veszélyezteti. ${ }^{72} \mathrm{E}$ szabályozásnál a jogalkotó figyelemmel volt arra, hogy a kamasz gyermek neveléséhez a gyermek részéről szükséges együttmüködés jobban biztosítható, ha az általa választott szülőnél kerül elhelyezésre. E szabály tehát az életkor megjelölése mellett a konkrét ügyben feltárt körülményekhez igazodva ismeri el a gyermek választási jogának a jelentőségét, a meghallgatását életkorára és érettségi fokára tekintettel tartja kötelezőnek. Ugyanakkor előfordulhat mégis olyan eset, hogy a 14. életévét betöltött gyermek sem tudja felmérni a valós érdekét, azaz azt, hogy az önálló döntése veszélyhelyzetet idézhet elő, így ilyen esetben - ahogy azt a jogirodalom is hangsúlyozza - a bíróság mellőzheti a gyermek által választott elhelyezést. ${ }^{73}$

\section{A vérségi származás megismeréséhez való jog}

A vérségi származás megismeréséhez való jog mint általános személyiségi jog az emberi méltósághoz való jog körébe tartozik. E joggal összefüggésben az Alkotmánybíróság több határozatában is kifejtette, hogy a vérségi származás kiderítése mindenkinek a legszemélyesebb joga, amelynek fontos aspektusa az önrendelkezéshez és az önazonossághoz való jog, ebböl következően mindenkinek joga van arra, hogy a vérségi származását kiderítse, illetve vérségi jogállását kétségbe vonja és azt felkutassa. ${ }^{74}$

A vérségi származás megismeréséhez való jogot számos nemzetközi, illetve hazai dokumentum, jogszabály is garantálja. Így például a Gyermekjogi Egyezmény 7.

70 Szeibert (2014): i. m., 33.

71 WeIss Emília: A gyermeki jogok és a szülői jogok és kötelességek gyakorlásának néhány újabb kérdése. Családi Jog, 2010/1, 1-12.

72 Ptk. 4:171. $§(4)$ bekezdés.

73 WeISS (2010): i. m., 5.

74 57/1991. (XI. 8.) AB határozat, $A B H$ 1991, 272. 982/B/1998. AB határozat, $A B H ~ 2006,1153$. 
cikkének 1. pontja kimondja, hogy a gyermeknek joga van ahhoz, hogy lehetőség szerint ismerje a szüleit.

A származás megismeréséhez való jog deklarálását az indokolja, hogy a gyermeknek ismernie és értenie kell saját élettörténetét, továbbá a származás megismerése fontos az identitás és az önértékelés szempontjából is. Így e gyermeki jog az identitáshoz való jog egyik megvalósulási formáját jelenti, amely az emberi méltósághoz való jogból vezethető le.

E gyermeki joggal kapcsolatban fontos megemlíteni, hogy a magyar jogrendszerben - más országok jogi szabályozásával ellentétben - a származás megismerésének lehetősége nem az eredeti anyakönyv megtekintésével, hanem a gyámhatóságtól kérhető tájékoztatással került szabályozásra. Ugyanakkor például Angliában a gyermek 18. életévének betöltése után jogosult kézhez venni az eredeti születési anyakönyvi kivonatot, miután egy támogató beszélgetésen részt vett. ${ }^{75}$

A Családjogi Könyvben a gyermek származás megismeréséhez való joga - a korábbi szabályozáshoz képest - fokozottabban érvényesül azáltal, hogy az új kódex differenciáltabb szabályozást tartalmaz. ${ }^{76}$ Így a törvény elöször azt szabályozza, hogy az örökbefogadott a gyámhatóságtól miről és milyen idős korban kérhet felvilágosítást, bővítve a szabályozást a testvér és a féltestvér adatainak megismerhetőségével. A Családjogi Könyv érintett rendelkezése értelmében a gyámhatóság a vér szerinti szülő, illetve a testvér, a féltestvér meghallgatása nélkül tájékoztatja a kérelmező gyermeket arról, hogy örökbe fogadták-e, él-e a vér szerinti szülöje, és a felderíthető adatok szerint van-e testvére, féltestvére. Ugyanakkor a vér szerinti szülöjének és testvérének természetes személyazonosító adatairól a gyermek csak a 14. életévének betöltésétöl - a törvényes képviselő hozzájárulása nélkül - kaphat információt, ekkor azonban - a személyes adatok tiszteletben tartásához füződő jog biztosítása érdekében - már szükséges a vér szerinti szülő és a testvér meghallgatása is. Ugyanis a korábbi szabályozás (Csjt. és Gyer. ${ }^{77}$ ) szerint nem volt egyértelmú, mi történik akkor, ha a vér szerinti szülö a személyes adatainak az örökbe fogadott részére való kiadásához nem járul hozzá. Így ebben az esetben ütközött egymással az örökbe fogadott gyermek vérségi származás megismeréséhez való joga, valamint a vér szerinti szülő személyes adatainak védelméhez való joga. A Családjogi Könyv azonban e két jog ütközését feloldotta, és egyértelművé tette, amennyiben a vér szerinti szülö és a testvér a személyazonosító adatainak a kiadásához nem járul hozzá, az örökbe adott gyermekkel nem kíván kapcsolatba lépni, úgy ezek az adatok nem közölhetőek az örökbe fogadott gyermekkel. E körben az új kódex a vér szerinti szülő és testvér személyes adatainak védelmét előnyben részesíti az örökbe fogadott gyermek vérségi származás megismeréséhez való jogával szemben. ${ }^{78}$ Ugyanakkor e jog hangsúlyosabbá válására tekintettel a Családjogi Könyv meghatározza azokat az eseteket is, amikor nincs szükség a vér szerinti szülő és a testvér

75 KatonÁné Pehr (2007): i. m., 537.

76 Ptk. 4:135. §.

77 A gyámhatóságokról, valamint a gyermekvédelmi és a gyámügyi eljárásról szóló 149/1997. (IX. 10.) Korm. rendelet.

78 NAVRATYIL Zoltán: Észrevételek az új Polgári Törvénykönyv tervezetével összefüggésben. Magyar Jog, 2012/11, 690-694. 
meghallgatására, ${ }^{79}$ így például akkor, ha az érintett személy ismeretlen helyen távol van. Végül a törvény rögzíti azokat az eseteket is, amikor nem közölhetőek a vér szerinti szülő és a testvér természetes személyazonosító adatai, ${ }^{80}$ így többek között akkor, ha az a kiskorú gyermek érdekeivel ellentétben áll. Ez utóbbira különösen akkor kerülhet sor, ha a vér szerinti szülő felügyeleti jogát a bíróság azért szüntette meg, mert a szülő felróható magatartásával gyermeke testi, értelmi vagy erkölcsi fejlődését súlyosan sértette vagy veszélyeztette.

\section{A megfelelő életszínvonalhoz való jog}

A Gyermekjogi Egyezmény 27. cikk 1. pontja alapján minden gyermeknek joga van olyan életszínvonalhoz, amely lehetővé teszi a kellő testi, szellemi, lelki, erkölcsi és társadalmi fejlődését. Elsősorban a szülők vagy a gyermekekért felelős más személyek alapvető feladata, hogy lehetőségeik és anyagi határaik között biztosítsák a gyermek fejlödéséhez szükséges életkörülményeket. ${ }^{81}$ Amennyiben pedig a szülök nem képesek a gyermek részére a megfelelő életszínvonalat biztosítani, az államnak kell közbelépnie. ${ }^{82}$

A gyermek megfelelő életszínvonalhoz való joga tehát abban az esetben érvényesül, amennyiben biztosított többek között a gyermek tartása, a gondozása, az egészségügyi ellátottsága, a rendezett lakáskörülmény, valamint, ha a szülők megfelelő anyagi-jövedelmi helyzete garantált.

Hazánkban a Gyermekjogi Egyezménnyel összhangban alkotmányos szinten, az Alaptörvényben is rögzítésre került a gyermeknek azon joga, hogy megfelelő testi, szellemi és erkölcsi fejlődéshez szükséges védelemben és gondoskodásban részesüljön. ${ }^{83}$ A 2011. december 31. napjáig hatályos Alkotmány ugyanezen megfogalmazást tartalmazta azzal, hogy rögzítette azt is, kik voltak kötelesek e védelmet és gondoskodást biztosítani. ${ }^{84} \mathrm{E}$ kötelezettek a család, az állam és a társadalom. Az Alkotmány e rendelkezésével összefüggésben Rózsás Eszter a Gyermekjogok címü könyvében úgy fogalmaz, hogy „nem kétséges, hogy ez az alkotmányi rendelkezés a gyermeket és annak jelzett jogait, valamint a család, az állam és a társadalom kapcsolódó kötelezettségeit alkotmányos alapértéknek minősíti". ${ }^{55}$ Bár az Alaptörvény konkrétan nem rögzíti a kötelezettek körét, ugyanakkor az államnak a gyermekek védelme és a gyermekjogok érvényesítése érdekében jelenleg is konkrét kötelezettségei vannak, mint például a jogi szabályozás kidolgozása. ${ }^{86} \mathrm{E}$ jogi szabályozás közé tartozik többek között a Családjogi Könyv is azáltal, hogy a családjogi viszonyok

79 Ptk. 4:135. § (3) bekezdés.

80 Ptk. 4:135. § (4) bekezdés a)-c) pontok.

81 Gyermekjogi Egyezmény 27. cikk 2. pont.

82 Gyermekjogi Egyezmény 27. cikk 4. pont.

83 Magyarország Alaptörvénye XVI. cikk (1) bekezdés.

84 A Magyar Köztársaság Alkotmányáról szóló 1949. évi XX. törvény 67. § (1) bekezdés.

85 RózsÁs Eszter: Gyermekjogok. Dialóg Campus Kiadó, Budapest-Pécs, 2011, 13.

86 RózsÁs: i. m., 20. 
rendezésénél, számos részletrendelkezésben a gyermek megfelelő életszínvonalhoz való jogának érvényesülését garantálja.

Így a szülői felügyelet gyakorlásának bírósági rendezése során az egyik legfontosabb mérlegelési szempont, hogy a gyermek testi, erkölcsi és szellemi fejlödése miként biztosítható a legkedvezőbben. ${ }^{87}$ Továbbá a szülöi felügyelet gyakorlásának elvei között a törvény meghatározza, hogy a szülöi felügyeletet a szülök a gyermek megfelelő testi, szellemi és erkölcsi fejlődésének érdekében, egymással együttmüködve kötelesek gyakorolni. ${ }^{88}$ Ennek alapján a szülöi felügyelet kiterjed a gyermek fizikai gondozására, ellátására és neveltetésének biztosítására. Ez jut kifejezésre a törvény azon rendelkezésében is, amely szerint a szülök joga és kötelezettsége, hogy a gyermeküket gondozzák, a gyermek megélhetéséhez és felnevelkedéséhez szükséges feltételeket biztosítsák. ${ }^{89}$

A szülők felelőssége tehát a gyermekük gondozása és nevelése területén kiemelkedő. Ugyanakkor leggyakrabban e körben követhetnek el a szülök olyan, a gyermek testi, szellemi, erkölcsi fejlődését sértő és veszélyeztető hibát, amely a szülői felügyelet szüneteltetését vagy megszüntetését vonhatja maga után. ${ }^{90}$

\section{A tartáshoz való jog}

A megfelelő életszínvonalhoz való jog magában foglal egy külön nevesített gyermeki jogot is: ez a tartáshoz való jog, amelyet többek között a Gyermekjogi Egyezmény 27. cikkének 1 . és 2 . pontja garantál. Az Alkotmánybíróság döntése szerint a kiskorú gyermek tartáshoz való joga alkotmányos alapjog, mivel a gyermek tartása, mint a testi fejlődéséröl való gondoskodás, a szülők alapvető alkotmányos kötelezettsége, és annak biztosítása a gyermek érdekeit szolgálja. Emiatt a gyermek érdekében a szülök jogainak bizonyos korlátozása sem alkotmányellenes, mert az a szülők alkotmányos kötelezettségeinek megvalósulását biztosítja. ${ }^{91}$ Az Alkotmánybíróság egy másik határozatában pedig úgy foglalt állást, hogy e gyermeki jog a gyermek létfontosságú érdekét és az Alkotmányban védett alapvető jogának megvalósulását szolgálja. Ugyanis a gyermek élete fenntartásának, szükségletei kielégítésének érdeke, és az ezzel összefüggő családjogi követelés teljesítéséhez füződő érdek kellő súlyú alkotmányos indoka annak, hogy a tartásdífizetési kötelezettséget az állam más kötelezettségektöl eltérően kezelje. ${ }^{92}$

A gyermek tartáshoz való jogának fokozottabb érvényesülését jelenti, hogy a Családjogi Könyv a családjogi tartást, és ezen belül a kiskorú gyermek tartását annak gyakoriságára és jelentőségére tekintettel - új szerkezetben, külön fejezetben, speciális és több kérdésben részletesebb szabályokkal rendezi. Így a törvény a rokontartás cím alatt három önálló fejezetet tartalmaz: az első a rokontartás álta-

\footnotetext{
87 Ptk. 4:167. § (2) bekezdés.

88 Ptk. 4:147. $\S(1)$ bekezdés.

89 Ptk. 4:152. $\S(1)$ bekezdés.

90 Ptk. 4:186. § és 191. §.

995/B/1990. AB határozat, $A B H$ 1993, 515.

92 20/1994. (IV. 16.) AB határozat, $A B H$ 1994, 106, III.3. pont.
} 
lános, valamennyi tartási típusra vonatkozó szabályaival foglalkozik, míg a második és a harmadik fejezet rendezi a különös tartási típusokat, azaz a kiskorú gyermek, valamint a továbbtanuló nagykorú gyermek tartásának a speciális szabályait. ${ }^{93}$ A rokontartásról szóló cím felépítése is jelzi, hogy a gyermek tartásának különös jelentősége van. A gyermektartás, különösen a kiskorú gyermeké azért igényel külön szabályozást, mert különösen védett és a tartásra sajátos módon rászoruló jogosultról van szó. Továbbá a gyermektartás fontosságát jelzi az is, hogy a Családjogi Könyv nemcsak a vér szerinti gyermek, hanem a mostohagyermek tartását is szabályozza. ${ }^{94}$

A kiskorú gyermek tartáshoz való joga szempontjából az egyik legfontosabb szabály a rászorultság vélelme. Ugyanis a kiskorú gyermek életkorából rendszerint az következik, hogy önmagát nem képes ellátni, és általában a létfenntartáshoz szükséges anyagiakkal sem rendelkezik. Így az esetek túlnyomó többségében rászorul arra, hogy eltartásáról a szülei gondoskodjanak. Ennek alapján a Családjogi Könyv - a tartáshoz való jog jelentőségére tekintettel - vélelmet állít fel a gyermeknek a tartásra való rászorultsága mellett. $E$ vélelem alkalmazásának lehetőségét azonban a törvény nem korlátozza a gyermek kiskorúságának idejére, így e vélelem a 18. életévét betöltött, de a 20. életévét el nem érő, középiskolai tanulmányokat folytató gyermekre is vonatkozik. ${ }^{95}$ Ugyanakkor e vélelem megdönthető például annak bizonyításával, hogy a gyermek képes a saját eltartásáról gondoskodni, vagy a gyermek munkával szerzett keresménnyel rendelkezik. ${ }^{96}$

A kiskorú gyermek tartáshoz való jogának kiemelt jelentőségét jelzi, hogy a kiskorúval szemben az érdemtelenség sem érvényesül. Ugyanis a Családjogi Könyv 4:194. § (2) bekezdéséből egyértelműen kitünik, hogy tartásra érdemtelen csak nagykorú lehet, mivel a nagykorú gyermektöl már elvárható, hogy ne tanúsítson olyan súlyosan felróható magatartást, amely miatt a kötelezettöl a tartása nem várható el.

E gyermeki jog messzemenő érvényesülését jelenti a szülők tartási kötelezettségét elöíró törvényi rendelkezés. A gyermektartás a szülök közös felelőssége. E körben pedig nincs jelentősége annak, hogy a szülők házasságban vagy élettársi kapcsolatban élnek-e, mivel a tartási kötelezettség a szülői (anyai, apai) jogállásból következik. Így a törvény a szülő tartási kötelezettségét olyan módon határozza meg, hogy a kiskorú gyermek tartására a szülő a saját szükséges tartásának a korlátozásával is köteles, kivéve, ha a gyermek indokolt szükségletei fedezhetőek. Végül a gyermek tartáshoz való jogának fontosságát jelzi, hogy amennyiben a szülök a gyermektartásdij kérdésében nem tudnak megállapodni, úgy arról a bíróság dönt. ${ }^{97} \mathrm{E}$ körben a törvény konkrétan meghatározza, milyen tényezőket (mindkét szülö jövedelmi és vagyoni viszonyait, a gyermek saját jövedelmét stb.) kell a bíróságnak figyelembe venni a gyermektartásdíj megállapításánál. ${ }^{98}$

93 A rokontartás szabályai a Ptk. 4:194. § 4:222. § között találhatóak.

94 Szeibert Orsolya: A rokontartás. In: Körös András (szerk.): Polgári Jog - Családjog - Az új Ptk. magyarázata III/VI. HVG-ORAC, Budapest, 2013, 320.

95 Ptk. 4:214. §.

96 Ptk. 4:215. $\S(1)$ bekezdés.

97 Ptk. 4:218. $\S(1)$ bekezdés.

98 Ptk. 4:218. § (2) és (3) bekezdés. 


\section{A kapcsolattartáshoz való jog}

A szülö-gyermek kapcsolattartás egyrészröl a házasság felbonthatóságával és a szülöi felügyeleti jogok kiszélesedésével nyert egyre nagyobb gyakorlati, majd elméleti jelentőséget. Másrészröl a kapcsolattartáshoz való jog a társadalmi viszonyok változásai folytán, azaz a válások számának növekedésével, új családmodellek és új párkapcsolatok kialakulásával, a szülö-gyermek viszony átalakulásával, valamint az alternatív konfliktuskezelési módszerek igényének felmerülésével kapott nagyobb hangsúlyt mind a jogalkotás, mind a jogalkalmazás területén. ${ }^{99} \mathrm{E}$ társadalmi változások révén az emberi jogok, így a gyermeki jogok is előtérbe kerültek, melyet jelez az is, hogy a Gyermekjogi Egyezmény 9. cikk 3. pontja kifejezetten rendelkezik a gyermek kapcsolattartáshoz való jogáról. Ennek alapján az egyezményben részes államok tiszteletben tartják a mindkét szülöjétöl vagy ezek egyikétöl különélő gyermeknek azt a jogát, hogy személyes kapcsolatot és közvetlen érintkezést tarthasson fenn mindkét szülőjével, kivéve, ha ez a gyermek legföbb érdekével ellenkezik.

A Családjogi Könyv alapvetően gyermeki jogként határozza meg a különélő szülővel való személyes és közvetlen kapcsolattartási jogot. ${ }^{100}$ Emellett a törvény a szülő oldaláról is rendezi a kapcsolattartás kérdését, amely szerint a gyermekétöl különélő szülő joga és egyben kötelessége a gyermekével kapcsolatot tartani. ${ }^{101}$ Bár az új szabályozás lényeges változást nem eredményezett a kapcsolattartás tekintetében, ugyanakkor - különösen a nemzetközi trendeknek megfelelően - e gyermeki jog fokozottabb érvényesülése figyelhető meg. Ezt támasztja alá egyrészről a gyermek tényleges családi kapcsolatainak fokozott védelme, a családi kapcsolatok megtartásához való jog mint alapelv hangsúlyosabb érvényesülése, valamint a határon átnyúló kapcsolattartási jogviták kiemelt szerepének kezelése. Másrészről e gyermeki jog fontossága nyilvánul meg azáltal, hogy a Családjogi Könyv a kapcsolattartást és az erre vonatkozó anyagi jogi rendelkezéseket a szülői felügyelet gyakorlásáról szóló fejezet egy külön pontjában szabályozza. Ugyanakkor e szabályozás továbbra is keretjellegü, mivel a kapcsolattartás eljárásjogi és végrehajtási szabályait a Gyvt. és a Gyer., valamint a jogalkalmazó (bíróság, gyámhatóság) tölti meg tartalommal.

Álláspontom szerint a gyermek kapcsolattartáshoz való jogának fokozott érvényesülését jelenti azon új családjogi rendelkezés, ${ }^{102}$ amely más hozzátartozók, elsődlegesen a nagyszülők, illetve a gyermekhez közel álló más személyek (testvér stb.) részére is biztosít kapcsolattartási jogot. ${ }^{103} \mathrm{E}$ személyi kört az új kódexben a kapcsolattartásra jogosultak között azért volt szükséges nevesíteni, mivel a szülök válását követően különösen a nagyszülök tapasztalják azt, hogy a gyermekkel együtt élő, a szülői felügyeletet gyakorló szülő az ellenséges érzelmeit, megbántottságát a másik szülő családtagjaira is kivetíti, és nem látja szívesen a korábbi rendszeres

99 Somfal Balázs: Kapcsolattartás, mint a gyermek emberi joga. HVG-ORAC, Budapest, 2009, 70-74.

100 Ptk. 4:178. § (1) bekezdés.

101 Ptk. 4:178. $§(2)$ bekezdés.

102 A szülő mellett a nagyszülő, a nagykorú testvér, a gyermek szülőjének testvére és szülőjének házastársa a Gyer. 28. § (1) bekezdése értelmében - már az új Polgári Törvénykönyv hatálybalépése előtt is - kérhette, illetve kérheti jelenleg is a gyámhatóságtól a kapcsolattartás szabályozását.

103 Ptk. 4:179. § (1) bekezdés. 
nagyszülő-unoka együttléteket. Másrészről a gyermek fejlődése, személyiségének kiteljesedése szempontjából, vagyis az identitáshoz való jog érvényesülése miatt is lényeges és kívánatos, hogy a törvényben meghatározott személyekkel a gyermek lehetőleg folyamatosan érintkezhessen. ${ }^{104}$

$E$ gyermeki jog fokozottabb érvényesülése figyelhető meg azáltal is, hogy a törvény a korábbinál nagyobb jelentőséget tulajdonít a gyermek tényleges családi kapcsolatainak. Így lehetővé teszi, hogy a volt mostohaszülő, a nevelőszülő, a gyám és az is, akinek a gyermekre vonatkozó apasági vélelmét a bíróság megdöntötte, a gyermekkel kapcsolatot tarthasson, ha a gyermek hosszabb időn keresztül e személy háztartásában nevelkedett. ${ }^{105} \mathrm{Ez}$ azért fontos, mivel a gyermek és az adott személy között kialakult érzelmi kapcsolat nem szűnik meg egyik napról a másikra. Másrészről a kapcsolattartás biztosítása segíthet a fokozatos elválásban, vagy a gyermek érdekeivel ellentétben nem álló, a gyermek életére kifejezetten pozitív hatást gyakorló további kapcsolat fenntartásában.

A határon átnyúló családi viszonyokban e gyermeki jog messzemenő érvényesülését garantálja a Családjogi Könyv azon új rendelkezése, amely a különélő szülö kapcsolattartási jogát kiterjesztette a gyermek meghatározott időtartamú külföldre vitelére. ${ }^{106} \mathrm{~A}$ Legfelsőbb Bíróság már korábban is hangsúlyozta, hogy a szülőtől különélő országban élő gyermeknek nemzetközi egyezményekben (különösen a Gyermekjogi Egyezményben és a Hágai Egyezményben ${ }^{107}$ ) deklarált alkotmányos joga, hogy a különélő szülőjével, annak hazájában, a saját anyanyelvi és kulturális közegében közvetlenül érintkezzen, saját identitását és rokonait megismerje. ${ }^{108,109}$

\section{8. Összegzés}

E tanulmányomban a Családjogi Könyvben garantált, gyermekeket érintő egyes alapelvek és jogok érvényesülését vizsgáltam. E részletes jogszabályi és jogirodalmi elemzés után álláspontom szerint az állapítható meg, hogy az új Ptk. Családjogi Könyvében a gyermeki jogok messzemenően érvényesülnek. Ezt támasztja alá egyrészröl egyes gyermeki jogok, így különösen a véleménynyilvánításhoz, a kapcsolattartáshoz, a tartáshoz, a vérségi származás megismeréséhez való jog - a korábbi családjogi rendelkezésekhez képest - részletesebb, differenciáltabb szabályozása. Másrészröl a gyermeki jogok fokozottabb érvényesülését jelenti, hogy a Családjogi Könyv immár törvényi szinten szabályozza az egységes családjogi ítélkezési gyakorlat megoldásait, értelmezéseit. Harmadsorban a gyermek érdekének és jogainak erőteljesebb figyelembevétele jelenik meg azokban a rendelkezésekben is,

104 MAKal: i. m., 277

105 Ptk. 4:179. § (3) bekezdés.

106 Ptk. 4:180. $\S(2)$ bekezdés.

107 A gyermekek jogellenes külföldre viteléröl szóló, 1980-ban, Hágában létrejött Egyezmény.

$108 \mathrm{EBH}$ 2007. 1610.

109 EBH 2001. 418. 
amelyek a határon átívelő családjogi jogviták (különösen a külföldi kapcsolattartás) rendezésével kapcsolatosak. Végül a gyermeki érdekek hangsúlyosabb érvényesülését szolgálja az is, hogy a mediációs eljárás a Családjogi Könyvben szabályozásra került.

\begin{abstract}
In Hungary, the new Civil Code came into force on $15^{\text {th }}$ March 2014. the fourth book of which (the Family Law Book) contains the rules of family law. These rules of family law have changed in some areas compared to what they were previously. For example, developments have occurred in the field of children's rights. In the current study the author examines the enforcement of children's rights guaranteed by the Family Law Book. As a main conclusion of this in-depth analysis, the author states that the new Civil Code ensures greater protection and better enforcement of children's rights. Namely, the Family Law Book determines the children's rights in more detail, particularly the right to freedom of opinion, the right to maintaining relationship, and the right to support. In addition, new paradigm changes can be noticed in the Family Law Book which are in connection with the change of parent-and-child relations and the greater consideration of children's rights and interests.
\end{abstract}

